\title{
Economic Elites in enlarged Europe
}

\author{
Katharina Bluhm, Vera Trappmann*
}

The introduction to the Special Issue on economic elites in Central Eastern Europe establishes a common understanding of elite research and the development of capitalism in Central Eastern Europe as developed during the 1990s. Since then, the composition of elites has been lost sight of by research. The article identifies areas which future research should look into and situates the German case in the broader debate.

Die Einleitung zu dem Sonderheft über Wirtschaftseliten in Mittelosteuropa rekonstruiert den Forschungsstand zu Eliten und Kapitalismus in Mittelosteuropa. Sie schafft damit eine gemeinsame Basis für die folgenden Analysen, gliedert den deutschen Fall in das Forschungsdesign ein und lokalisiert Forschungslücken.

* Katharina Bluhm, Prof., University of Osnabrück. Main research areas: Varieties of capitalism in Central Eastern Europe, relocation of production, economic and management sociology. Corresponding address: katharina.bluhm@uni-osnabrueck.de.

Vera Trappmann, Lecturer, Friedrich - Schiller - University. Main research areas: Political economy in Central Eastern Europe, employment relations and europeanisation in the enlarged EU. Corresponding address: vera.trappmann@uni-jena.de. 


\section{Introduction}

Studying elites gained popularity with the breakdown of the socialist systems. Elites were seen as the drivers of social change, the constructors of the new economic and political system. While the old system was demolished from below, post-communist transformation - or such was the expectation - was carried out from above. Much attention was therefore paid to the question of who the new elites would be. Would the old elites be able to stay in power, or would they disappear with the system they created and sustained? Thus, the classical questions of elite research were most prominently studied during the early 1990s: recruitment of elites via reproduction or circulation; the sociostructural composition; the origins and backgrounds of elites. Interest diminished when political stabilisation and economic reform seemed to have been achieved or at least seemed underway. The focus of interest shifted to the functioning of the new systems, the institutions needed, the role of external organisations shaping the economic paths, and integration with the European Union (Kutter/Trappmann 2006).

Therefore, much of the research on elites in Central Eastern Europe is not only outdated but also historical in the sense that it described a special moment of transformation, and the activities of the early pioneers of capitalism. Twenty years later, the economies in Central Eastern Europe have changed dramatically, witnessing privatisation, extensive GDP growth, internationalisation, and integration into European chains of production. It is thus due time to once again study the elites in these consolidated capitalisms, their composition as well as their recruitment and career paths, and their roles in shaping Central Eastern European economies. In this special issue of the Journal of East European Management Studies, we would like to offer a fresh view on economic elites in Central Eastern Europe ${ }^{1}$ We present recent research from two angles: classical elite studies investigating the composition of elites and their characteristics; and class analysis, studying the role of economic elites in society and how the elite stabilized its power. This variety of approaches calls for a broad definition of elites. We propose an understanding of business elites as individuals inhabiting leading positions and in control of resources in domestic economies. Before we present the single contributions, we will look back briefly at the most prominent research to date on business elites in Eastern Europe in order to establish a common ground for analysis.

1 Compare also Tholen et al. 2007. Central Eastern Europe consists of the Viségrad countries, the Baltic states, Bulgaria and Roumania. In this article, we mainly treat the Viségrad countries and East Germany. 


\section{The origin of the new economic elite}

Transformation literature distinguished at least four different sources of economic actors in the emerging capitalist systems. While not all of them can be counted as elite, it makes sense to start with acknowledging all four types of new capitalist actors. Some authors recognized, for small and medium-sized enterprises, a capitalism from below, through the legalising of the informal economy (Böröcz/Róna-Tas 1995), by increasing self-employment (Hanley 1999), or by creating new private business (Borkowski/Marcinkowski 2008), which only in few cases has produced an economic elite; it represented for the most part a strategy of refuge from poverty, and not a basis for elite recruitment. Proponents of political capitalism argue that the new economic elite of large business derived from the socialist nomenclature and its bureaucratic apparatus (Hankiss 1990; Staniszkis 1991). While this argument has been contested, we have to acknowledge the large number of Polish enterprises, for example, that are ruled by former party functionaries (Wesolowski 2004). Advocates of postcommunist managerialism argue that the new elite consists of members of the former technocracy, in particular former managers of large state-owned enterprises (Szalai 1994; Szelenyi 1995; Eyal et al. 1998). Recruitment took place mostly from deputy managers in state enterprises, and it was therefore often referred to as "intergenerational vertical reproduction" or as "the deputies" revolution" Hatschikjan (1998:258). According to Mateju and Hanley (1998) this vertical reproduction of economic elites has been the outcome of a power struggle among the elite that started already in the 1980s. The more extensive elite circulation was before 1989, the lower it was after that date. The Polish case best illustrates this variety of origins. The business elite is composed of people with a broad range of social backgrounds: besides the former managers of state-owned enterprises and the self-made men who transformed small firms into major companies are found former Solidarity activists and members of the self-employed sector who gained control in state-owned enterprises in early 1990s, as well as immigrants, politicians and top civil servants who moved from politics and administration to the business sector, and speculators and those with much-sought-after skills (Federowicz et al. 2005).

The success of economic actors depended on the capital they had available (Stoica 2004). In most cases, it was not economic but political or cultural capital that was transformed into economic. This leads to the second peculiarity of elite formation of the Central Eastern Europe capitalism: the "capitalism from without".

\section{Capitalism without capitalists?}

In their seminal contribution, Eyal et al. (1998) state that in Central Eastern Europe capitalism is not only made without capitalists as driving actors ("capitalism without capitalists"), they also imply that the new economic elite 
failed to become a propertied class ${ }^{2}$ While Eyal et al. argue that the cause for the absence of a new "grande bourgeoisie" in Central Eastern Europe lies in the recombination of property (Stark 1996), i.e. in hybrid private-state ownership structures, this no longer holds true. During the 1990s, large companies were mainly privatised to foreign investors, and large new companies were also often foreign direct investments. Thus, most of the countries - especially the small ones - show a high transnationalisation of their economy. Only in few cases did large private companies remain autonomous. On the transnationalisation index of UNCTAD, countries like Hungary, Slovakia or the Czech Republic show very high scores, comparable with the smallest states of the European Union.

Table 1. UNCTAD Transnationalisation index

\begin{tabular}{|l|c|c|}
\hline & $\mathbf{1 9 9 9}$ & $\mathbf{2 0 0 2}$ \\
\hline Estonia & 23.2 & 39.0 \\
\hline Czech Republic & 17.6 & 30.9 \\
\hline Hungary & 27.6 & 30.1 \\
\hline Slovakia & 7.1 & 27.1 \\
\hline Latvia & 13.2 & 23.3 \\
\hline Lithuania & 13.2 & 23.3 \\
\hline Slovenia & 7.9 & 22.3 \\
\hline Poland & 11.5 & 15.6 \\
\hline Romania & 9.4 & 12.1 \\
\hline Ukraine & 4.8 & 10.3 \\
\hline Germany & 10.6 & 14.3 \\
\hline France & 9.4 & 13.5 \\
\hline UK & 14.5 & 16.8 \\
\hline USA & 8.2 & 7.7 \\
\hline
\end{tabular}

Source: UNCTAD 2005; Drahokoupil 2008

Transnationalisation has been achieved mainly by integration into the valueadded chains of multinational companies. It results in an unbalanced relation between inward and outward investments, and the high proportion of a country's export and employment figures represented by multinationals. Also exceptional is the high penetration of foreign capital in the financial sector. This model of integration has made some authors term the East European capitalisms "foreignled" (Vliegenthart 2005), or even "dependent" capitalism, linked to the "victory of globalizers" (Staniszkis 1991). Recent research corrects this lopsided vision

2 Business ownership became possible only for small firms, which, as Róna-Tas argued, often was the result of the formalization of the informal economy. The new entrepreneurial class often consisted of managers of large firms who run small companies in parallel to their state positions. Osborn/Slomczynski (2005) therefore argue that, "Making capitalism without capitalists has been possible because the reserve army of capitalists, in the form of an entrepreneurial class, already existed." (ibid. 226). 
of dependent capitalism, observing an upgrading in the value-added chains, arguing that it represents a chance for Central Eastern Europe to become more independent of workbench production (Bohle/Greskovits 2007; Bluhm 2007).

This model of capitalism, based on foreign direct investment, also called "from without", is only typical for Central Eastern Europe; other post-communist countries have built up different types of capitalism. According to King and Szelenyi (2005) the different paths were dependent on patterns of class conflict and interclass alliances. While in Central Eastern Europe the alliance between technocrats and critical intellectuals, both disapproving of the political bureaucracy, limited political capitalism and produced more or less "liberal capitalism", in Eastern Europe und most notably in Russia, the political apparatus retained its power and transformed itself into a kind of bourgeoisie leading to "patrimonial capitalism" "from above" (Eyal et al. 1998 called this phenomenon "capitalists without capitalism"). In countries like China, capitalism was emerging "from below" where state nomenclature existed side by side with nascent capitalists leading to a so-called "hybrid capitalism".

In this capitalism from without, the new business elite did not suffer from its lack of property, as they tended to reward themselves with high salaries, without risking their assets by investing in firms (King 2001). What this mindset means for the functioning of a market economy is yet to be seen. But it seems clear that in the three patterns different dispositions of actors will shape the format of capitalism and its institutions.

\section{Characteristics of the new elite}

King/Szelenyi (2005) and Eyal et al. (2003), in their attempt to explain the variation of elite formation in post-communist countries, were the first to link elite research to the "varieties of capitalism" debate in Central Eastern Europe. According to them, the introduction of capitalism in Central Eastern Europe has been mainly a project of the alliance of the intelligentsia and the technocrats who blocked a wide-range privatisation by the old nomenclature. Accordingly, cultural capital dominated the social structures of post-communist winners. Most of the business elites ranked highly in the previous system's status structure, with managerial positions, and were better educated, especially with training in engineering and economics. Consequently, they were mainly male, between forty and fifty, with years of experience in state-owned enterprises or institutions (Federowicz 2005). Of these, the biggest winners were members of technocratic fraction of the old ruling elites, in particular those who were promoted to office in the 1980s, when technical competence took precedence over party loyalty in the recruitment of administrators (Eyal et al. 1998). The individual skills and cultural capital helped them to become the new business elite (Grancelli/Chiesi 2006). These characteristics were valid during the 1990s, when privatisation was still ongoing and economies were not yet consolidated. Little is known about the 
characteristics of the new elite. Given the still existent though negative linkage of the elite with the old system, it is likely that transnational companies tend to recruit in particular young cadres externally, often with an international education, forming them through intra-company training and career paths into some kind of transnational experts, who could work in any country in that particular company. Federowicz (2005) calls this new business class "young tigers" characterising them as disembedded from local contexts. Probably also the qualification basis has changed, economic degrees becoming more popular. The studies presented in this volume, while not able to answer all the questions concerning this issue, will help in addressing a number of them.

\section{How does the German case fit in?}

The German transformation towards a market economy is often perceived as not comparable with other post-communist countries, due to unification and the ensuing institution transfer. This might have been the reason why King/Szelenyi (2005) did not expand their typology to East Germany. Yet the East German formation of the economic elite shares in a broad sense at least some features of their Central East European neighbours: a high intergenerational vertical reproduction from the second management level ("the deputies' revolution"); and a limitation of domestic ownership to small- and medium-sized business. Larger companies, in as far as they survived the shock of unification, belong to multinational companies mostly of West German origin. In this respect, East Germany fits into the Central East European pattern of a "capitalism from without", and can even be interpreted as an extreme case of this pattern. The German case is extreme because the breakdown of large state companies and deindustrialization was much more radical. In addition, while the topmanagement of multinational companies in Central Eastern Europe consists of indigenous managers, a consequence of the absence of large-scale ownership in the German case is that East Germans in the highest management ranks and in trade associations operating at a national level are still rare.

\section{The contributions to this issue}

All four articles in this volume are united in two aspects: first, they assume that there has been a close link between elite formation and phase of transition; and second, they underline that this has led to a fragmentation of the economic elite. Coming from different schools, the authors highlight different aspects of economic elite formation: the composition and characteristics (Lengyel, Martens), and their role in transforming capitalism (Jasiecki, Drahokoupil). They also apply different definitions of elite. Each contribution focuses on a special segment of elites: Bernd Martens for East Germany focuses on the leaders of strong local and regional enterprises, which are often medium-sized; György Lengyel's article centres on the Hungarian transnational and 
multipositional elite, powerful people who, due to an accumulation of positions in companies or government, influence the national economy; Krzysztof Jasiecki mainly deals with the Polish business elite - domestic entrepreneurs of large domestic enterprises and managers of multinational companies; and Jan Drahokoupil concentrates on a segment of elites that gained its power from collaborating with and serving foreign-direct investors (FDI) in all Viségrad countries.

In his contribution, Drahokoupil underlines that with foreign-led capitalism, the state gained a new role managing the insertion of local economy into the flow of global capitalism, often in competition with other states. In this competition state, Drahokoupil recognizes a special segment of elites that administers and facilitates this process, thereby becoming the most powerful group in the Viségrad countries. He calls this domestic elite the "comprador service sector", those offering their services to foreign investors. This group consists of local branches of global consulting firms, domestic consulting agencies, investment banks and state officials that deal with FDI, actors often switching between functions in government, consultancy and management position in transnational companies. While this section of the elite is not a propertied class, it benefits from its support of the foreign capital, both economically and by increased political influence.

Jasiecki also divides the Polish economic elite along the lines of their functions, but those functions as seen over time: the breakthrough elite, the transition elite and the consolidation elite. According to Jasiecki, while early elites were composed of social groups with very different genesis and status, the new elite has become more homogenous, due to a generational change and similar education in international business schools. Part of the consolidation elite consists of managers of foreign-owned business, and this part of that elite develops its own coherent social pattern.

Lengyel observes similar patterns among segments of elites in Hungary. While education, recruitment and career pattern seem similar among different segments of elites, they develop different social and cultural peculiarities. Lengyel speaks of the Westernisation of the transnational elite. In contrast to Hungary, Poland, and the Czech Republic, East Germany is not only the most homogenous but also astonishingly the one with greatest continuity of economic elites. Martens demonstrates the high reproduction rate of the East German economic elite still in 2005, with career patterns unchanged, and stable business relations between managers and employees. The economic elite's current characteristics - such as age structure, job mobility, company ownership, and qualifications - still seem to derive from the window of opportunities that existed in the early 1990s. The only remarkable development in time is the shift from managerial capitalism to family capitalism. Those elder managers, who reached their positions in the early 1990s, gained shares of the companies and tend to transfer their business 
ownership and leadership within family or larger kinship. Among the East German elite, neo-liberal attitudes are far more widespread than among its Western counterpart, a feature which is also shared among all Central Eastern European economic elites.

To conclude this brief introduction, it seems that the younger generation has developed many new ideas about business: a Polish survey of students in business schools has found that students consider managers dishonest, shortsighted, ignorant, uneducated, and incompetent, while they themselves want to become honest and fair managers, and change things (Kostera 1995:676), and it would seem that thorough research is needed to evaluate the ideas of the new generation of managers and economic elites. On worldviews, mentalities, and identities we know even less than we do about the composition of the elites.

\section{References}

Bluhm, K. (2007): Experimentierfeld Ostmitteleuropa? Deutsche Unternehmen in Polen und der Tschechischen Republik. Wiesbaden: VS-Verlag.

Bohle, D./Greskovits, B. (2007): Neoliberalism, embedded neoliberalism and neocorporatism: Towards transnational capitalism in Central-Eastern Europe, in: West European Politics, 30, 3, 443-466.

Borkowski, T./Marcinkowski, A. (2008): From the 'Wild West' Towards Europe: Change and Challenges in SMEs in Poland, in: Bluhm K./Schmidt R. (eds.): Change in SMEs. Towards a New European Capitalism? Houndmills et al.: Palgrave, 185-200.

Böröcz, J./Róna-Tas, Á. (1995): Emergence/Formation of the New Economic Elites: Hungary, Poland, and Russia, in: Theory and Society, 24, 751-781.

Drahokoupil, J. (2008): Globalization and the state in Central and Eastern Europe: The politics of foreign direct investment, Routledge.

Eyal, G./Szelényi, I./Townsley, E. (1998): Making Capitalism Without Capitalists. Class Formation and Elite Struggles in Post-Communist Central Europe, London and New York.

Eyal, G./Szelényi, I./Townsley, E. (2003): On Irony: An Invitation to Neoclassical Sociology, in: Thesis Eleven, 73, 1, 5-41.

Federowicz, M./Jasiecki, K./Weselowksi W. (2005): The Business Elites of Poland, in: Steiner, H./Tamas, P. (eds.): The business elites of East Central Europe, Berlin: trafo Verlag, 13-58.

Grancelli, B./Chiesi, A.M. (2006): Elites in the Making and their Organizational Behaviour: Cases in Russia and the Balkans, in: Dallago, B. (ed.): Transformation and European Integration: The Local Dimension, Basingstoke: Palgrave, 127-141.

Hankiss, E. (1990): East European Alternatives. Oxford, Clarendon Press.

Hanley, E. (1999): Cadre Capitalism in Hungary and Poland: Property Accumulation among Communist-era Elites, in: East European Politics and Societies, 1999, 14, 143 - 178. 
Hatschikjan, M.A. (1998): Zeitenwende und Elitenwandel in Osteuropa, in: Hatschikjan, M. A./Altmann, F.L. (eds.): Eliten im Wandel. Politische Führung, wirtschaftliche Macht und Meinungsbildung im neuen Osteuropa, Paderborn and München: Ferdinand Schöningh, 251-269.

King, L.P./Szelényi, S. (2005): Post-Communist Economic Systems, in: Smelser, N.J./Swedberg, R. (eds.): The Handbook of Economic Sociology. 205-232.

King, L.P. (2001): The Basic Features of Post-Communist Capitalism: Firms in Hungary, the Czech Republic, and Slovakia, Westport CT: Praeger Press.

Kostera, M. (1995): Differing Managerial Responses to Change in Poland, in: Organization Studies, 16, 4, 673-697.

Kutter, A./Trappmann, V. (2006). Das Erbe des Beitritts: Zur Analyse von Europäisierungseffekten in mittel- und osteuropäischen Gesellschaften, in: Kutter, A. /Trappmann, V. (eds.) Das Erbe des Beitritts. Europäisierung in Mittel- und Osteuropa.Baden-Baden: Nomos Verlag: 13-55.

Mateju, P./Hanley, E. (1998): Die Herausbildung ökonomischer und politischer Eliten in Ostmitteleuropa, in: Hatschikjan, M. A./Altmann, F.L. (eds.): Eliten im Wandel. Politische Führung, wirtschaftliche Macht und Meinungsbildung im neuen Osteuropa, Paderborn and München: Ferdinand Schöningh: 145-171.

Osborn, E./Slomczynski, K.M. (2005): Open for Business: The Persistent Entrepreneurial Class in Poland, Warszawa: IFiS.

Róna-Tas, Á./Böröcz, J. (2000): Bulgaria, the Czech Republic, Hungary, and Poland. PreSocialist and Socialist Business Elites, in: Higley, J./Lengyel, G. (eds.): Elites after State Socialism. Lanham and Boulder: Rowman and Littlefield Publishers: 209-227.

Staniszkis, J. (1991): "Political Capitalism" in Poland, in: East European Politics and Societies, 5, 1, 127-141.

Stark, D. (1996) Recombinant Property in East European Capitalism, in: American Journal of Sociology, 101, 4 , 993-1027.

Stoica, C.A. (2004): From Good Communists to Even Better Capitalists? Entrepreneurial Pathways in Post-Socialist Romania, in: East European Politics and Societies, 18, 2, 236-277.

Szelényi, I./Szelényi, S. (1995): Circulation or reproduction of elites during the postcommunist transformation of Eastern Europe, in: Theory and Society, 24, 615-638.

Tholen, J./Lane, D. /Lengyel, G. (eds.) (2007): Restructuring of the Economic Elites after State Socialism. Recruitment, Institutions and Attitudes. Stuttgart: ibidem Verlag.

UNCTAD (2005): World Investment Report, New York/Geneva: United Nations.

Vliegenthart, A. (2005): EU Membership and the Rise of a Foreign-Led Type of Capitalism in the Czech Republic, http://www.allacademic. com/meta/p_mla_apa_research_citation/ 0/7/0/6/1/pages70617/p70617-1.php

Wesolowski, W. (2004): Social Change in Poland. What have we learned so far? in: International Journal of Sociology, 34, 3, 15-34. 